\title{
Obesity parameters as predictors of early development of cardiometabolic risk factors
}

\author{
Parâmetros de obesidade como preditores de desenvolvimento \\ precoce de fatores de risco cardiometabólicos
}

Miria Suzana Burgos ${ }^{1}$

Cézane Priscila Reuter ${ }^{2}$

Lia Gonçalves Possuelo ${ }^{1}$

Andréia Rosane de Moura Valim ${ }^{1}$

Jane Dagmar Pollo Renner ${ }^{1}$

Luciana Tornquist ${ }^{1}$

Debora Tornquist ${ }^{1}$

Anelise Reis Gaya ${ }^{3}$

${ }^{1}$ Mestrado em Promoção da Saúde, Universidade de Santa Cruz do Sul (UNISC). Av. Independência 2293/bl. 42/4206. 96815-900 Santa Cruz do Sul RS Brasil. mburgos@unisc.br

${ }^{2}$ Departamento de Educação Física e Saúde, UNISC.

${ }^{3}$ Escola de Educação Física, Universidade Federal do Rio Grande do Sul.

\begin{abstract}
The scope of this study was to verify the association between different overweight and obesity parameters and the metabolic risk profile among school-age students. The randomized cross-sectional study included 1254 children and adolescents, aged 7 to 17 , from a city in southern Brazil. Body mass index (BMI), waist circumference (WC) and percentage of fat (PF), measured at the triceps and based on subscapular skinfold thickness, were used as the parameters to evaluate overweight/obesity status. Systolic blood pressure $(S B P)$, total cholesterol, high-density lipoprotein cholesterol (HDL), low-density protein cholesterol $(L D L)$ and triglycerides were also measured. The metabolic risk profile was calculated based on the sum of the $z$ score of the metabolic variables adjusted by age. A three-model Poisson analysis was used to verify the association between BMI, WC and PF with metabolic risk profile. BMI showed the highest probability for developing metabolic risk compared with WC (overweight - PR: 1.63 and obesity - PR: 3.87 ) and $P F$ (overweight $-P R$ : 1.62 and obesity - PR: 2.92). In conclusion, BMI seems to be a better parameter of overweight/obesity than WC and PF in the assessment of metabolic risk among youths.
\end{abstract}

Key words Obesity, Risk factors, Child, Adolescent
Resumo O objetivo deste estudo foi verificar associação entre diferentes parâmetros de sobrepeso e obesidade com o perfil de risco metabólico em escolares. O estudo transversal randomizado incluiu 1.254 crianças e adolescentes, com idades entre 7 e 17 anos, de uma cidade do sul do Brasil. O indice de massa corporal (IMC), a circunferência da cintura (CC) e o percentual de gordura (PG), avaliado através das medidas das dobras cutâneas tricipital e subescapular, foram usados como parâmetros para avaliar sobrepeso/obesidade. Pressão arterial sistólica (PAS), colesterol total, lipoproteina de alta densidade (HDL), lipoproteina de baixa densidade $(L D L)$ e triglicerídeos também foram mensurados. O perfil de risco metabólico foi calculado com base no somatório do escore $z$ das variáveis metabólicas ajustadas por idade. Três modelos de regressão de Poisson foram utlizados para verificar a associação entre IMC, CC e PG com o perfil de risco metabólico. Os dados demostram que o IMC foi o parâmetro que apresentou a maior associação com o desenvolvimento de risco metabólico, em comparação com CC (sobrepeso $R P: 1,63$ e obesidade - RP: 3,87) e PG (sobrepeso - RP: 1,62 e obesidade - RP: 2,92). Conclui-se que o IMC parece ser um melhor parâmetro de sobrepeso/obesidade do que CC e PG, na avaliação do risco metabólico em escolares.

Palavras-chave Obesidade, Fatores de risco, Criança, Adolescente 


\section{Introduction}

Currently, overweight and obesity are becoming an emergent public health problem, even in the young population ${ }^{1,2}$. Obesity has been considered one of the main risk factors for the early development of several comorbidities, such as type II diabetes, high blood pressure, certain types of cancer and other health problems ${ }^{3-5}$. In Brazil ${ }^{6}$, as in other developed countries ${ }^{7}$, approximately $30 \%$ of youngsters are classified as overweight or obese.

Consequently, as in the USA and other countries with similar prevalence rates of overweight and obesity, cardiovascular risk factors have become a new health problem among the youth population. In this context, several studies have reported high prevalence rates of type 2 diabetes, hypertension, insulin resistance and dyslipidemias along with an increasing prevalence of metabolic syndrome ${ }^{8-11}$. Evidence from American National Survey has revealed that approximately $10 \%$ of the youth population exhibits clustering of cardiometabolic abnormalities ${ }^{12}$. Thus, some common adult diseases are already being diagnosed in children and adolescents. These diseases are typically stable from childhood until adulthood and are associated with an elevated risk of cardiovascular events later in adult life $\mathrm{e}^{13,14}$.

In addition, it is essential to understand the relationships between various parameters used to evaluate overweight/obesity and cardiovascular risk factors and how each parameter can indicate the early development of cardiovascular risk factors in youth ${ }^{15}$, particularly Brazilian youth ${ }^{16}$.

Therefore, our study was based on the necessity of determining a simple parameter for indicating obesity among schoolchildren and adolescents and the consequences of such a parameter. In addition to better measurement techniques, several reports have described the use of body mass index (BMI), waist circumference (WC) and percentage of fat $(\mathrm{PF})$ based on skinfolds for adiposity measurements ${ }^{15,17,18}$. However, if any of these parameters showed a strong correlation with the metabolic profile, it could be used to identify early development of cardiovascular disease (CVD) among the young ${ }^{15}$. Thus, the purpose of this study was to verify the association between different parameters of overweight/ obesity and cardiometabolic risk factors and to estimate the early incidence of cardiometabolic risk factors among the youth population.

\section{Materials and methods}

This research is a part of the Schoolchildren's Health Project, which is aimed at studying the prevalence and incidence rates of youth overweight and obesity and their causes and consequences. The population consisted of schoolchildren and adolescents from Santa Cruz do Sul in southern Brazil. The study of this longitudinal cohort was started in 2004, and data from this study comprised the third phase. Thus, the sample included 1254 children and adolescents, both boys and girls, aged 7-17 years, who were randomly selected from 18 schools (14 in the urban area, and 4 in the rural area) around the city. This project was approved by the Ethics Committee on Research on Human Beings of the University of Santa Cruz do Sul, and was performed in accordance with the Declaration of Helsinki. Schools approved the study protocol, and all parents signed an informed consent form. The students were apparently healthy and free of medical treatment.

BMI was used to assess overweight/obesity, and the students were later classified as normal or overweight/obese according to international cut off points ${ }^{19}$. Weight and height were measured without shoes immediately after the student awoke in the morning before breakfast. WC was measured (using a metric tape $[\mathrm{cm}]$ ) with the individual standing in an upright position, with the hands hanging down close to the body. The WC was measured at the narrower part of the trunk, between the ribs and the outer edge of the upper iliac bone and the hip at the greater trochanter level. The students were defined as overweight if their values were $>80^{\text {th }}$ percentile and obese if their values were $>90$ th percentile ${ }^{20}$.

PF was evaluated using the triceps and subscapular skinfold thicknesses, as measured using a Lange compass. Subsequently, the equation described by Slaugther et al. ${ }^{21}$ was used, and the PF was classified according to Lohman ${ }^{22}$; at-risk children and adolescents were classified as moderately high (overweight), high and very high risk (obese).

Blood pressure was measured according to the VI Brazilian Guidelines on Hypertension ${ }^{23}$ using a sphygmomanometer and stethoscope; measurement were taken on the student's right arm with the student in a sitting position after $10 \mathrm{~min}$ of rest. One of three size cuffs was used based on the student's arm circumference. Two measurements were performed prior to breakfast. If there was a large difference between these two measure- 
ments, a third measurement was performed. An average of the measurements was used.

Cardiorespiratory fitness was evaluated with a nine-minute walk/run test on students wearing proper clothing and sneakers in the same athletic track. The results obtained (in meters traveled) were assessed using Tables recommended by PROESP-BR ${ }^{24}$, according to age and gender, and subsequently classified into fit (healthy levels of cardiorespiratory fitness) and unfit (low levels of cardiorespiratory fitness).

\section{Cardiometabolic risk profile}

Biochemical parameters (glucose, total cholesterol, high-density lipoprotein cholesterol [HDL-C] and triglycerides) were assessed using serum samples, which were analyzed using Miura One automated equipment (I.S.E., Rome, Italy) and a commercial DiaSys kit (DiaSys Diagnostic Systems, Germany). Low-density lipoprotein cholesterol (LDL-C) was calculated according the Friedewald equation ${ }^{25}$. For sample characterization, lipid profile was classified according to $\mathrm{Na}$ tional Heart, Lung, and Blood Institute ${ }^{26}$.

Similar to what has been proposed by Andersen et al. ${ }^{27}$ and recently used by Mota et al..$^{28}$, the cardiometabolic variables were computed as a continuous risk score based on the following: glucose; total cholesterol (TC); triglycerides (TG); HDL-C; LDL-C and systolic blood pressure (SBP). For each of these variables, a Z-score was computed to indicate higher CVD risk. The HDL-C Z-score was multiplied by -1 to indicate higher CVD risk with increasing value. Then, a Metabolic Risk Score (MRS) was determined by summing the Z-scores of all of the individual risk factors adjusted by age. A lower MRS is indicative of a better overall CVD risk factor profile. To calculate the odds ratio, metabolic risk was dichotomized at the cut-off value plus $1 \mathrm{SD}$, thus identifying children with cluster risk. High metabolic risk was considered when the individual had a score that was greater than or equal to $1 \mathrm{SD}$ of this score.

\section{Statistical analysis}

Data analyses were performed using SPSS 20.0 for Windows (IBM, Chicago, USA). The frequencies of youth overweight/obese based on BMI, WC and PF analyses were determined. The kappa coefficient was used to verify the concordance analyses between BMI, WC and PF. A three-model Poisson analysis was used to verify the association between BMI, WC and PF mass based on the metabolic risk profile as a dependent variable. The results are shown as $95 \%$ confidence intervals (CIs) and prevalence ratio (PR) values considering a significance level of 5\%.

\section{Results}

The sample characteristics are summarized in Table 1. Our sample consisted of boys (55.5\% from urban areas and $44.5 \%$ from rural areas) and girls (60.8\% from urban areas and 39.2\% from rural areas) aged between 7 to 17 years (boys: $11.73 \pm 3.04$ and girls: $12.00 \pm 3.01$ ). Differences between boys and girls in terms of mean cardiorespiratory fitness, WC, PF, TC, TG, LDL-C and SBP were observed $(p<0.05)$. Boys generally showed better cardiometabolic risk factor values compared with the girls: cardiorespiratory fitness (boys: $1415.54 \pm 301.29$ vs. girls: $1190.87 \pm$ 570.76), TC (boys: $178.02 \pm 38.26$ vs. girls: 183.86 \pm 37.56 ), TG (boys: $62.34 \pm 29.50$ vs. girls: 71.33 \pm 33.19 ) and LDL-C (boys: $104.49 \pm 37.75$ vs. girls: $109.60 \pm 36.51$ ). Girls showed higher mean values for WC (girls: $67.45 \pm 10.16$ vs. boys: 65.47 \pm 9.17 ) and PF (girls: $25.02 \pm 6.28$ vs. boys: 20.93 \pm 8.59 ).

Considering the three parameters used to indicate overweight and obesity, as shown in Figure 1, our results showed a similar prevalence of youth with overweight/obesity. However, concordance analyses revealed a higher association between BMI and WC (kappa $=0.657$; p $=0.02$ ) than between PF and BMI (kappa $=0.490 ; \mathrm{p}=$ $0.02)$ or WC (kappa $=0.362 ; \mathrm{p}=0.02)$.

In Figure 2, the data indicated that approximately $45 \%$ of obese youth were classified based on their metabolic risk profiles. Nevertheless, if considering the PF, only $28 \%$ of youth in the metabolic risk profile group were classified.

Table 2 illustrates three different models of Poisson regression, including BMI, WC and PF, categorized as normal and overweight/obese. In all models, gender, residential zone (rural and urban areas) and cardiorespiratory fitness were classified at low and high levels for health. Boys compared with girls (PR: 1.48; CI: 1.15-1.91) and rural compared with urban areas (PR: 1.60; CI: 1.25-2.04) showed increased PRs for cardiometabolic profile risk. These results were observed in models 1, 2 and 3. However, cardiorespiratory fitness was not statistically significant.

In addition, youth categorized as overweight/ obese based on BMI (PR: 2.88; CI: 2.25-3.68), 
Table 1. Sample characteristics of the students stratified by gender. Santa Cruz do Sul, RS, 2012.

\begin{tabular}{|c|c|c|c|}
\hline & $\begin{array}{c}\text { Male }(\mathrm{N}=568 ; 45.3 \%) \\
\mathrm{n}(\%)\end{array}$ & $\begin{array}{c}\text { Female }(\mathrm{N}=686 ; 54.7 \%) \\
n(\%)\end{array}$ & $\mathbf{p}^{\S}$ \\
\hline Residence Area & & & 0.032 \\
\hline Urban & $315(55.5)$ & $417(60.8)$ & \\
\hline Rural & $253(44.5)$ & $269(39.2)$ & \\
\hline Age (years) ${ }^{*}$ & $11.73(3.04)$ & $12.00(3.01)$ & 0.108 \\
\hline $\operatorname{BMI}\left(\mathrm{kg} / \mathrm{m}^{2}\right)^{*}$ & $20.02(3.81)$ & $20.01(3.89)$ & 0.986 \\
\hline Normal & $379(66.7)$ & $510(74.3)$ & 0.002 \\
\hline Overweight/obesity & $189(33.3)$ & $176(25.7)$ & \\
\hline $\mathrm{WC}(\mathrm{cm})^{*}$ & $67.46(10.16)$ & $65.47(9.17)$ & $<0.001$ \\
\hline Normal & $448(78.9)$ & $566(82.5)$ & 0.060 \\
\hline Obesity & $120(21.1)$ & $120(17.5)$ & \\
\hline $\mathrm{PF}(\%)^{*}$ & $20.93(8.59)$ & $25.02(6.28)$ & $<0.001$ \\
\hline Normal & $299(52.6)$ & $354(51.6)$ & 0.379 \\
\hline Overweight/obesity & $269(47.4)$ & $332(48.4)$ & \\
\hline CRF (meters) ${ }^{*}$ & $1415.54(301.29)$ & $1190.78(570.76)$ & $<0.001$ \\
\hline Fit & $306(53.9)$ & $311(45.3)$ & 0.002 \\
\hline Unfit & $262(46.1)$ & $375(54.7)$ & \\
\hline Total cholesterol $(\mathrm{mg} / \mathrm{dL})^{*}$ & $178.02(38.26)$ & $183.86(37.56)$ & 0.007 \\
\hline Acceptable & $252(44.4)$ & $255(37.2)$ & \\
\hline Borderline & $176(31.0)$ & $227(33.1)$ & 0.025 \\
\hline High & $140(24.6)$ & $204(29.7)$ & \\
\hline HDL-C $(\mathrm{mg} / \mathrm{dL})^{*}$ & $56.50(11.86)$ & $56.26(11.28)$ & 0.718 \\
\hline Acceptable & $465(81.9)$ & $572(83.4)$ & \\
\hline Borderline & $66(11.6)$ & 75 (10.9) & 0.752 \\
\hline Low & $37(6.5)$ & $39(5.7)$ & \\
\hline $\mathrm{LDL}-\mathrm{C}(\mathrm{mg} / \mathrm{dL})^{*}$ & $104.49(37.75)$ & $109.65(36.51)$ & 0.014 \\
\hline Acceptable & $348(61.2)$ & $374(54.5)$ & \\
\hline Borderline & $118(20.8)$ & $128(18.7)$ & 0.001 \\
\hline High & $102(18.0)$ & $184(26.8)$ & \\
\hline Triglycerides $(\mathrm{mg} / \mathrm{dL})^{*}$ & $62.34(29.50)$ & $71.33(33.19)$ & $<0.001$ \\
\hline Acceptable & $477(84.0)$ & $510(74.3)$ & \\
\hline Borderline & $65(11.4)$ & $129(18.8)$ & $<0.001$ \\
\hline High & $26(4.6)$ & $47(6.9)$ & \\
\hline $\mathrm{SBP}(\mathrm{mmHg})^{*}$ & $105.08(13.62)$ & $102.32(11.97)$ & $<0.001$ \\
\hline Normotensive & $466(82.0)$ & $612(89.2)$ & 0.001 \\
\hline Borderline & $67(11.8)$ & $44(6.4)$ & \\
\hline Hypertension & $35(6.2)$ & $30(4.4)$ & \\
\hline Cardiometabolic risk & & & 0.010 \\
\hline No & $492(86.6)$ & $560(81.6)$ & \\
\hline Yes & $76(13.4)$ & $126(18.4)$ & \\
\hline
\end{tabular}

* Data expressed as mean (SD); SD: standard deviation; BMI: body mass index; WC: waist circumference; PF: percentage of fat; CRF: cardiorespiratory fitness; HDL-C: HDL cholesterol; LDL-C: LDL cholesterol. SBP: systolic blood pressure; ${ }^{\varsigma}$ independent $\mathrm{t}$ test for means and qui-square or Fisher exact test for categorical variables.

WC (PR: 2.26; CI: 2.26-3.70) and PF (PR: 2.18; CI: 1.65-2.86) showed similar prevalence ratios to the cardiometabolic profile risk.

Conversely, in Table 3, when we analyzed BMI, WC and PF categorized in both obese and overweight groups, our data revealed a higher PR of youth with a cardiometabolic profile risk based on BMI (PR: 4.48; CI: 3.38-5.95) obesity catego- ries compared with WC obesity categories $\left(90^{\text {th }}\right.$ percentile) (PR: 3.87; CI: 2.92-5.13) and PF (PR: 2.91; CI: 2.16-3.92). The overweight or obese categories for PF showed similar prevalence ratios for cardiometabolic profile risk; however, for both BMI and WC, obese youth exhibited higher PRs than youth categorized as overweight and, consequently, those categorized based on PF. 


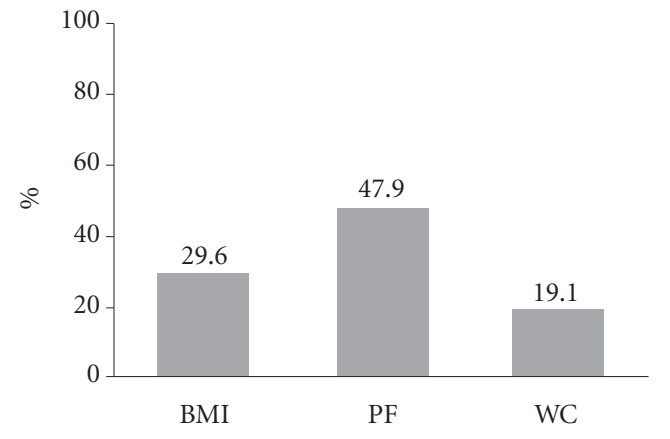

Figure 1. Occurence of youth overweight/obesity stratified by BMI, PF and WC.

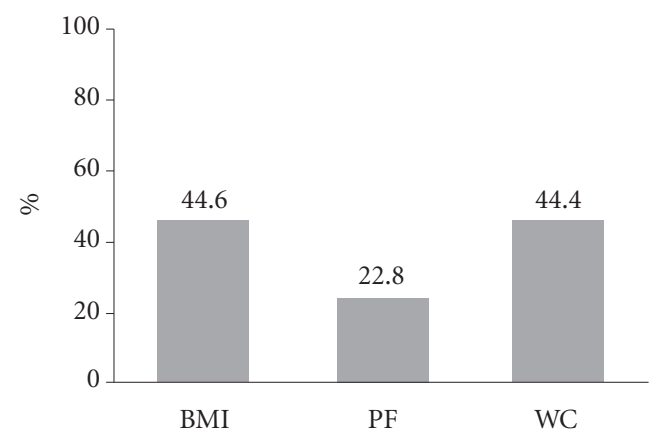

Figure 2. Ocurrence of youth with cardiometabolic risk profile stratified by indicators of overweight/ obesity.

\section{Discussion}

The results of our study have provided relevant considerations about the early development of cardiometabolic risk factors among a representative sample of youth. Firstly, there is evidence that a significant number of youth develop overweight and obesity early. If overweight and obesity are analyzed together, their occurrence ranges from $19.1 \%$ based on WC to $47.9 \%$ based on PF as determined from two skinfold measurements. As a consequence, this early risk might be associated with an elevated number of youth with metabolic risk profiles: approximately $45 \%$ of youth in the obese category. Finally, our study showed that for Brazilian children, BMI is possibly the main predictive parameter associated with cardiometabolic risk, and obese compared with overweight youth showed a higher risk of developing metabolic profiles early. Further, more boys than girls and children who live in ru-
Table 2. Relationships between parameters in normal vs. overweight/obese youth with cardiometabolic risk factor profiles. Santa Cruz do Sul, RS, 2012.

\begin{tabular}{|c|c|c|}
\hline & PR $(95 \% \mathrm{CI})$ & $\mathbf{p}$ \\
\hline \multicolumn{3}{|l|}{ Model 1} \\
\hline \multicolumn{3}{|l|}{ BMI } \\
\hline Normal & 1 & \\
\hline Overweight/obesity & $2.88(2.25-3.68)$ & $<0.001$ \\
\hline \multicolumn{3}{|l|}{ Zone } \\
\hline Urban & 1 & \\
\hline Rural & $1.60(1.26-2.05)$ & $<0.001$ \\
\hline \multicolumn{3}{|l|}{ Gender } \\
\hline Male & 1 & \\
\hline Female & $1.48(1.15-1.91)$ & 0.002 \\
\hline \multicolumn{3}{|c|}{ Cardiorespiratory fitness } \\
\hline Fit & 1 & \\
\hline Unfit & $1.02(0.80-1.32)$ & 0.858 \\
\hline \multicolumn{3}{|l|}{ Model 2} \\
\hline \multicolumn{3}{|l|}{ Waist circumference } \\
\hline Normal & 1 & \\
\hline Obesity & $2.90(2.27-3.70)$ & $<0.001$ \\
\hline \multicolumn{3}{|l|}{ Zone } \\
\hline Urban & 1 & \\
\hline Rural & $1.49(1.16-1.90)$ & 0.002 \\
\hline \multicolumn{3}{|l|}{ Gender } \\
\hline Male & 1 & \\
\hline Female & $1.46(1.14-1.88)$ & 0.003 \\
\hline \multicolumn{3}{|c|}{ Cardiorespiratory fitness } \\
\hline Fit & 1 & \\
\hline Unfit & $0.99(0.77-1.28)$ & 0.949 \\
\hline \multicolumn{3}{|l|}{ Model 3} \\
\hline \multicolumn{3}{|l|}{ Percentage of fat } \\
\hline Normal & 1 & \\
\hline Overweight/obesity & $2.18(1.66-2.87)$ & $<0.001$ \\
\hline \multicolumn{3}{|l|}{ Zone } \\
\hline Urban & 1 & \\
\hline Rural & $1.58(1.23-2.02)$ & $<0.001$ \\
\hline \multicolumn{3}{|l|}{ Gender } \\
\hline Male & 1 & \\
\hline Female & $1.39(1.07-1.80)$ & 0.013 \\
\hline \multicolumn{3}{|c|}{ Cardiorespiratory fitness } \\
\hline Fit & 1 & \\
\hline Unfit & $1.05(0.81-1.36)$ & 0.704 \\
\hline
\end{tabular}

PR: prevalence ratio; BMI: body mass index; FIT: healthy levels of cardiorespiratory fitness; UNFIT: low levels of cardiorespiratory fitness.

ral areas exhibited increased PRs for developing cardiometabolic risk profiles.

Therefore, our data seems to be consistent with other studies that showed approximately $30 \%$ of children and adolescents were classified as overweight and obese ${ }^{1,6,29}$. The results are more alarming when based on the data on PF, which indicated that approximately $47.9 \%$ of youth are 
Table 3. Relationships between various parameters of normal vs. overweight and obese youths with cardiometabolic risk factor profiles. Santa Cruz do Sul, RS, 2012.

\begin{tabular}{|c|c|c|}
\hline & PR $(95 \%$ CI $)$ & $\mathbf{p}$ \\
\hline \multicolumn{3}{|l|}{ Model 1} \\
\hline BMI & 1 & \\
\hline Normal & $2.24(1.67-3.01)$ & $<0.001$ \\
\hline Overweight/obesity & $4.49(3.38-5.96)$ & $<0.001$ \\
\hline \multicolumn{3}{|l|}{ Zone } \\
\hline Urban & 1 & \\
\hline Rural & $1.56(1.22-1.98)$ & $<0.001$ \\
\hline \multicolumn{3}{|l|}{ Gender } \\
\hline Male & 1 & \\
\hline Female & $1.53(1.19-1.96)$ & 0.001 \\
\hline \multicolumn{3}{|c|}{ Cardiorespiratory fitness } \\
\hline Fit & 1 & \\
\hline Unfit & $0.96(0.74-1.23)$ & 0.740 \\
\hline \multicolumn{3}{|l|}{ Model 2} \\
\hline Waist circumference & 1 & \\
\hline Normal & $1.63(1.17-2.28)$ & 0.004 \\
\hline Obesity & $3.87(2.92-5.13)$ & $<0.001$ \\
\hline \multicolumn{3}{|l|}{ Zone } \\
\hline Urban & 1 & \\
\hline Rural & $1.37(1.07-1.76)$ & 0.013 \\
\hline \multicolumn{3}{|l|}{ Gender } \\
\hline Male & 1 & \\
\hline Female & $1.56(1.21-2.00)$ & 0.001 \\
\hline \multicolumn{3}{|c|}{ Cardiorespiratory fitness } \\
\hline Fit & 1 & \\
\hline Unfit & $0.96(0.74-1.25)$ & 0.776 \\
\hline \multicolumn{3}{|l|}{ Model 3} \\
\hline Percentage of fat & 1 & \\
\hline Normal & $1.62(1.16-2.26)$ & 0.005 \\
\hline Overweight/obesity & $2.92(2.17-3.93)$ & $<0.001$ \\
\hline \multicolumn{3}{|l|}{ Zone } \\
\hline Urban & 1 & \\
\hline Rural & $1.62(1.26-2.08)$ & $<0.001$ \\
\hline \multicolumn{3}{|l|}{ Gender } \\
\hline Male & 1 & \\
\hline Female & $1.50(1.16-1.94)$ & 0.002 \\
\hline \multicolumn{3}{|c|}{ Cardiorespiratory fitness } \\
\hline Fit & 1 & \\
\hline Unfit & $1.01(0.78-1.31)$ & 0.933 \\
\hline
\end{tabular}

PR: prevalence ratio; BMI: body mass index; Fit: healthy levels of cardiorespiratory fitness; Unfit: low levels of cardiorespiratory fitness.

overweight/obese; these results may have been influenced by the method used to evaluate PF two skinfold measurements, which may overestimate the PF in children who have thick skinfold thicknesses ${ }^{30}$. In fact, based on the kappa concordance test, PF showed a lower kappa coefficient compared with BMI and WC. In our data, PF indicated a larger number of youth in the obese group, approximately three times more than that with BMI and WC, but a weaker relationship with BMI and WC.

Several studies around the world have indicated prevalence rates similar to those detected in our BMI and WC data: recently, a trends study that included youth from different states in Brazil showed that since 2003, the prevalence rates of overweight and obesity in youth have been stable, with approximately $30 \%$ of youth being classified as overweight and obese ${ }^{6}$. Ogden et al. ${ }^{1}$ performed a trends study and reported similar results, indicating a high prevalence of overweight and obesity among the American youth population; however, a study by Flores et al. ${ }^{6}$ showed that the prevalence has stabilized.

As a consequence, cardiometabolic risk factors are prevalent among the youth ${ }^{3,5,15,31}$. In our data, approximately $45 \%$ of the youth exhibited metabolic risk profiles. These results have led to several concerns described by public health researchers, such as the necessity for understanding the main factors that are associated with this new public health threat. Nevertheless, if obesity is the main risk factor, what is the best way to measure overweight and obesity among the youth when we consider the relationship of various parameters with the cardiometabolic profile?

Therefore, different predictors could be associated with the development of cardiometabolic risk factors ${ }^{15,18}$. Nevertheless, consequences of lifestyle are evidenced as a main risk factor associated with this high occurrence of cardiovascular risk factors among the youth population ${ }^{31,32}$; thus, high levels of physical activity and healthy eating habits seem to be a good approach for preventing and treating these youth disorders ${ }^{33}$.

From a public health perspective, our data indicated a higher association between BMI and cardiometabolic risk profile among the youth, with a moderate to strong correlation with WC. These results could be considered in public health policies aimed at preventing the early development of CVD risk factors. These results are consistent with several published studies on European and American youth ${ }^{15,18}$. Jago et al. ${ }^{15}$ showed that routine monitoring of BMI should be performed by health professionals; however, additional information on disease risk may be provided by assessing WC. These results are consistent with our data, as the relationship between WC and the cardiometabolic risk profile was also strong. Lawlor et al..$^{18}$ produced similar results; however, as a conclusion, they suggest that the measurement 
of WC or direct assessments of fat mass during childhood do not seem to be associated with cardiovascular risk factors in adolescence any more than BMI. Nevertheless, we did not find similar studies with similar results in Brazilian youth.

In contrast with several studies ${ }^{31,34}$, our results did not show a significant association between cardiorespiratory fitness and cardiometabolic risk factors, possibly because BMI could be a moderate variable in the relationship between cardiorespiratory fitness and cardiometabolic risk profile or because we did not treat overweight and obesity separately from normal youth. Furthermore, our data indicated a higher risk of developing cardiometabolic risk profiles early for boys and youth who live in rural areas. These results indicated that youth lead industrialized lives in rural areas. In Santa Cruz do Sul, rural areas show a higher prevalence of low income, and large numbers of parents do not complete more than the first few years of school. Therefore, low income levels could be considered a risk factor for obesity among Brazilian youth. These results are in contrast with results reported several years ago, which showed that low income levels were associated with being underweight.

\section{Collaborations}

MS Burgos contributed to the preparation and coordination of the study and data collection, as well as helped write the manuscript. CP Reuter contributed to the study design, data collection, laboratory work, data analysis and wrote the manuscript. LG Possuelo, ARM Valim and JDP Renner contributed to the study design, data collection, laboratory work and helped write the manuscript. L Tornquist and D Tornquist contributed to the data collection, laboratory work and helped write the manuscript. AR Gaya assisted in the preparation of the study, data analysis and helped write the manuscript. All authors read and approved the final manuscript.
Despite several limitations of the current study, we were able to verify a relationship between cardiovascular profile risk with three different indicators of overweight and obesity in a representative sample of children and adolescents. There are a considerable number of obese youth, and many of them display cardiometabolic risk profiles. Furthermore, overweight and obese youth exhibited different risks for developing cardiometabolic risk factors; the BMI measurement seems to be the best way of identifying youth with metabolic risk profiles.

In conclusion, our study showed that high BMIs (youth categorized as obese), rural area and male gender are the main predictors of cardiometabolic risk profiles. In addition, our data indicate a high prevalence of overweight and obese youth; this group has a higher risk of developing a cardiometabolic risk profile early in life. Therefore, our results suggest that BMI measurement could be a valuable method of identifying youth with cardiometabolic risk based on epidemiologic studies and could be an important approach for health professionals aimed at preventing the early development of cardiometabolic risk factors.

\section{References}

1. Ogden CL, Carroll MD, Kit BK, Flegal KM. Prevalence of childhood and adult obesity in the United States, 2011-2012. JAMA 2014; 311(8):806-814.

2. Wang Y, Lobstein T. Worldwide trends in childhood overweight and obesity. Int J Pediatr Obes 2006; 1(1): 11-25.

3. Alvarez MM, Vieira AC, Moura AS, da Veiga GV. Insulin resistance in Brazilian adolescent girls: association with overweight and metabolic disorders. Diabetes Res Clin Pract 2006; 74(2):183-188.

4. Chiarelli F, Marcovecchio ML. Insulin resistance and obesity in childhood. Eur J Endocrinol 2008; 159(Supl. 1):S67-74.

5. Daniels SR, Arnett DK, Eckel RH, Gidding SS, Hayman LL, Kumanyika S, Robinson TN, Scott BJ, St Jeor S, Williams CL. Overweight in children and adolescents: pathophysiology, consequences, prevention, and treatment. Circulation 2005; 111(15):1999-2012.

6. Flores LS, Gaya AR, Petersen RD, Gaya A. Trends of underweight, overweight, and obesity in Brazilian children and adolescents. J Pediatr 2013; 89(5):456-461.

7. Dehghan M, Akhtar-Danesh N, Merchant AT. Childhood obesity, prevalence and prevention. Nutr J 2005; 4(24):1-8. 
8. Chiolero A, Cachat F, Burnier M, Paccaud F, Bovet P. Prevalence of hypertension in schoolchildren based on repeated measurements and association with overweight. J Hypertens 2007; 25(11):2209-2217.

9. Cook S, Weitzman M, Auinger P, Nguyen M, Dietz WH. Prevalence of a metabolic syndrome phenotype in adolescents: findings from the third National Health and Nutrition Examination Survey, 1988-1994. Arch Pediatr Adolesc Med 2003; 157(8):821-827.

10. Ekelund U, Anderssen S, Andersen LB, Riddoch CJ, Sardinha LB, Luan J, Froberg K, Brage S. Prevalence and correlates of the metabolic syndrome in a population-based sample of European youth. Am J Clin Nutr 2009; 89(1):90-96.

11. Jago R, Harrell JS, McMurray RG, Edelstein S, El Ghormli L, Bassin S. Prevalence of abnormal lipid and blood pressure values among an ethnically diverse population of eighth-grade adolescents and screening implications. Pediatrics 2006; 117(6):2065-2073.

12. de Ferranti SD, Gauvreau K, Ludwig DS, Neufeld EJ, Newburger JW, Rifai N. Prevalence of the metabolic syndrome in American adolescents: findings from the Third National Health and Nutrition Examination Survey. Circulation 2004; 110(16):2494-2497.

13. Chen W, Srinivasan SR, Li S, Xu J, Berenson GS. Metabolic syndrome variables at low levels in childhood are beneficially associated with adulthood cardiovascular risk: the Bogalusa Heart Study. Diabetes Care 2005; 28(1):126-131.

14. Park MH, Sovio U, Viner RM, Hardy RJ, Kinra S. Overweight in childhood, adolescence and adulthood and cardiovascular risk in later life: pooled analysis of three British birth cohorts. PLoS One 2013; 8(7):1-6.

15. Jago R, Mendoza JA, Chen T, Baranowski T. Longitudinal associations between BMI, waist circumference, and cardiometabolic risk in US youth: monitoring implications. Obesity 2013; 21(3):E271-279.

16. Moser DC, Giuliano ICB, Titski ACK, Gaya AR, Coelho-e-Silva MJ, Leite N. Indicadores antropométricos e pressão arterial em escolares. J Pediatr 2013; 89(3):243249.

17. Freedman DS, Ogden CL, Berenson GS, Horlick M. Body mass index and body fatness in childhood. Curr Opin Clin Nutr Metab Care 2005; 8(6):618-623.

18. Lawlor DA, Benfield L, Logue J, Tilling K, Howe LD, Fraser A, Cherry L, Watt P, Ness AR, Davey Smith G, Sattar N. Association between general and central adiposity in childhood, and change in these, with cardiovascular risk factors in adolescence: prospective cohort study. BMJ 2010; 341:c6224.

19. Cole TJ, Bellizzi MC, Flegal KM, Dietz WH. Establishing a standard definition for child overweight and obesity worldwide: international survey. BMJ 2000; 320(7244):1240-1243.

20. Taylor RW, Jones IE, Willians SM, Goulding A. Evaluation of waist circumference, waist-to-hip ratio, and the conicity index as screening tools for high trunk fat mass, as measured by dual-energy X-ray absorptiometry, in children aged 3-19 y. Am J Clin Nutr 2000; 72(2):490-495.

21. Slaughter MH, Lohman TG, Boileau RA, Horswill CA, Stillman RJ, Van Loan MD, Bemben DA. Skinfold equations for estimation of body fatness in children and youth. Hum Biol 1988; 60(5):709-723.
22. Lohman TG. The use of skinfold to estimate body fatness on children and youth. JOPERD 1987; 58(9):98102.

23. Sociedade Brasileira de Cardiologia. Sociedade Brasileira de Hipertensão. Sociedade Brasileira de Nefrologia. VI Diretrizes Brasileiras de Hipertensão. Arq Bras Cardiol 2010; 95(Supl. 1):1-51.

24. Projeto Esporte Brasil. PROESP-BR [Internet]. Manual. [acessado 2014 maio 12]. Available from: http:// www.proesp.ufrgs.br

25. Friedewald WT, Levy RI, Fredrickson DS. Estimation of the concentration of low-density lipoprotein cholesterol in plasma, without use of the preparative ultracentrifuge. Clin Chem 1972; 18(6):499-502.

26. National Heart, Lung, and Blood Institute. Expert panel on integrated guidelines for cardiovascular health and risk reduction in children and adolescents. Bethesda: $\mathrm{Na}-$ tional Heart, Lung, and Blood Institute; 2012.

27. Andersen LB, Wedderkopp N, Hansen HS, Cooper AR, Froberg K. Biological cardiovascular risk factors cluster in Danish children and adolescents: the European Youth Heart Study. Prev Med 2003; 37(4):363-367.

28. Mota J, Santos R, Moreira C, Martins C, Gaya A, Santos MP, Ribeiro JC, Vale S. Cardiorespiratory fitness and TV viewing in relation to metabolic risk factors in Portuguese adolescents. Ann Hum Biol 2013; 40(2):1571562.

29. Pedroni JL, Rech RR, Halpern R, Marin S, Roth LR, Sirtoli M, Cavalli A. Prevalência de obesidade abdominal e excesso de gordura em escolares de uma cidade serrana no sul do Brasil. Cien Saude Colet 2013; 18(5):1417-1425.

30. Freedman DS, Horlick M, Berenson GS. A comparison of the Slaughter skinfold-thickness equations and BMI in predicting body fatness and cardiovascular disease risk factor levels in children. Am J Clin Nutr 2013; 98(6):1417-1424.

31. Bergmann GG, de Araújo Bergmann ML, Hallal PC. Independent and combined associations of cardiorespiratory fitness and fatness with cardiovascular risk factors in Brazilian youth. J Phys Act Health 2014; 11(2):375-383.

32. Andersen LB, Sardinha LB, Froberg K, Riddoch CJ, Page AS, Anderssen SA. Fitness, fatness and clustering of cardiovascular risk factors in children from Denmark, Estonia and Portugal: the European Youth Heart Study. Int J Pediatr Obes 2008; 3(Supl. 1):58-66.

33. Freitas LKP, Cunha Júnior AT, Knackfuss MI, Medeiros HJ. Obesidade em adolescentes e as políticas públicas de nutrição. Cien Saude Colet 2014; 19(6):1755-1762.

34. Ekelund U, Anderssen SA, Froberg K, Sardinha LB, Andersen LB, Brage S. Independent associations of physical activity and cardiorespiratory fitness with metabolic risk factors in children: the European youth heart study. Diabetologia 2007; 50(9):1832-1840.

Artigo apresentado em 13/08/2014

Aprovado em 11/02/2015

Versão final apresentada em 13/02/2015 